\title{
Quality of life of individuals with cleft lip and palate pre- and post-surgical correction of dentofacial deformity*
}

\author{
Qualidade de vida de indivíduos com fissura labiopalatina pré e \\ pós-correção cirúrgica da deformidade dentofacial \\ Calidad de vida de individuos con fisura labiopalatina pre y post \\ corrección quirúrgica de la deformidad dentofacial
}

\section{Marli Luiz Beluci', Katia Flores Genaro ${ }^{1}$}

\section{How to cite this article:}

Beluci ML, Genaro KF. Quality of life of individuals with cleft lip and palate pre- and post-surgical correction of dentofacial deformity. Rev Esc Enferm USP. 2016;50(2):216-221. DOI: http://dx.doi.org/10.1590/S0080-623420160000200006

\footnotetext{
* Extracted from the thesis "Qualidade de vida de indivíduos com fissura labiopalatina: avaliação pré e pós-correção cirúrgica da deformidade dentofacial”, Programa de Pós-Graduação em Ciências da Reabilitação, Hospital de Reabilitação de Anomalias Craniofaciais, Universidade de São Paulo, 2014.

${ }^{1}$ Universidade de São Paulo, Hospital de Reabilitação de Anomalias Craniofaciais, Programa de Pós-Graduação em Ciências da Reabilitação, Bauru, SP, Brazil.
}

\begin{abstract}
Objective: To assesses the quality of life and the impact of oral health conditions in the pre- and post-surgical correction of dentofacial deformity of individuals with cleft lip and palate. Method: Quantitative and prospective study in a referral hospital in the period from June 2011 to May 2013. A total of 50 participants responded the questionnaires World Health Organization Quality of Life - Bref (WHOQOL-Bref) and Oral Health Impact Profile - 14 (OHIP-14), approximately 3 days before and 3 to 12 months after surgery. The " $t$ " test for paired samples and Wilcoxon test were used for statistical analysis with a significance level of 5\%. Results: After surgery, differences were found in the domains: Physical, Psychological, Environmental and General Questions of the WHOQOL-Bref and domains: Psychological Discomfort, Psychological Disability, Social Disability, Handicap and Overall Score of OHIP-14. Conclusion: Surgical correction of dentofacial deformity improved quality of life and had positive impact of oral health condition.
\end{abstract}

\section{DESCRIPTORS}

Quality of Life; Orthognathic Surgery; Cleft Lip; Cleft Palate; Maxillofacial Abnormalities; Nursing. 


\section{INTRODUCTION}

Cleft lip and palate is considered the most common craniofacial malformations that affect the lip, the alveolar ridge and/or palate, and when untreated, results in aesthetic, functional and psychosocial impairment, besides affecting social interactions ${ }^{(1)}$. This malformation originates between the $4^{\text {th }}$ and $12^{\text {th }}$ week of gestation, has a multifactorial etiology and is associated with genetic and environmental factors. In Brazil, the prevalence is 1 per 650 births $^{(1)}$.

The institution specialized in the treatment of craniofacial malformations where the present study was developed, the reconstructive surgery of cleft lip and palate: cheiloplasty and palatoplasty for correction of the lip and palate, respectively, comprise the primary surgery ${ }^{(1)}$. The process of rehabilitation of this malformation requires interdisciplinary approach involving different specialties ${ }^{(2)}$, with multidisciplinary approach ${ }^{(1)}$, in which the nursing professional plays a fundamental role ${ }^{(3)}$.

In addition to the primary surgeries, other surgical procedures may be required to correct anatomical, functional and aesthetic problems, depending on the specificity of the case ${ }^{(4)}$. The dentofacial deformity, such as anteroposterior maxillary deficiency may develop and thus, interfere with the self-acceptance and may result in negative impact on the integration of the individual in society ${ }^{(1)}$. The performance of orthognathic surgery is justified to benefit dental occlusion, the aesthetics of the face and oral functions ${ }^{(4)}$. Rehabilitation aims to provide full social inclusion of these individuals ${ }^{(1)}$.

At all stages of rehabilitation, the nurse plays a critical role, especially in the formulation of care protocols on the basis of scientific evidence ${ }^{(3)}$. The nursing care is present in interventions for therapeutic success, including preoperative guidance, prevention of postoperative complications, nutritional care and oral hygiene. In this research, the promotion of care through educational guidelines is evident, in which the family must get involved for the maintenance of care after hospital discharge $e^{(3,5)}$.

Even in cases without cleft lip and palate, the presence of dentofacial deformity may interfere with aspects of quality of life $(\mathrm{QoL})$ and thus, the benefits of correcting this deformity is favored accordingly ${ }^{(6-10)}$. The evaluation of these aspects can be used as an outcome measure of treatment and has been applied in different areas involved in health rehabilitation, which helps the teams improvement of services in the pursuit of patient well-being ${ }^{(11)}$ as well as the planning of health care and clinical interventions ${ }^{(12)}$.

The interest in the QoL concept in health care has been growing and contributed to the promotion of research in institutions by professional staff who work with people affected by various diseases ${ }^{(11)}$. Among the developed instruments for studies involving QoL, constructed and translated for use in different countries, cultures and people, including Brazil, are: the World Health Organization Quality of Life - Bref (WHOQOL-Bref) suitable for assessment of $\mathrm{QoL}^{(13)}$; and the Oral Health Impact Profile - 14 (OHIP-14) to indicate the dimensions of QoL affected by oral health condition ${ }^{(14-15)}$.

In this study we chose to adopt the definition of QoL proposed by the World Health Organization (WHO): "individuals' perceptions of their position in life in the context of the culture and value systems in which they live and in relation to their goals, expectations, standards and concerns"(13,16).
Since both dentofacial deformities, such as cleft lip and palate affect QoL, it is asked whether in such cases the QoL is really changed after surgical treatment of dentofacial deformity, as it is believed that the orthognathic surgery is really expected by individuals due to the aesthetic and functional benefits. The hypothesis tested in this study is that surgery promotes change in aspects of QoL and a positive impact of oral health. The aim of the study was to evaluate the quality of life and the impact of oral health conditions in the pre- and post-surgical correction of dentofacial deformity of individuals with cleft lip and palate.

\section{METHOD}

Quantitative and prospective study in a public referral hospital. Individuals with cleft lip and palate operated, aged 18 years and over were included, and in hospital routine to perform corrective surgery of dentofacial deformity. Individuals with other craniofacial anomalies associated with cleft, neurological diseases or syndromes, according to notes in the medical records were excluded. The eligible cases in the preoperative in the institution, from June 2011 to May 2013 were assessed, totaling 80 individuals. However, the sample consisted of 50 individuals who were assessed pre- and postoperatively because of all cases interviewed in the preoperative period, since 30 of them did not conduct the interview in the postoperative period for various reasons, such as having missed the interview scheduled or not performing surgery.

In the pre- and postoperatively periods, through interviews, two instruments were applied to assess QoL, the World Health Organization Quality of Life (WHOQOL-Bref) and Oral Health Impact Profile (OHIP-14). The WHOQOLBref refers to the short version of WHOQOL-100 proposed by the World Health Organization, adapted and validated to Brazil, selected because it includes questions that met the study objective, adding reliable answers and for being easy to use $^{(13)}$. This instrument consists of 26 questions, two questions of general aspects (one concerning the $\mathrm{QoL}$ and another concerning health), and other 24 questions divided into four domains: Physical, Psychological, Social Relationships and Environment ${ }^{(13)}$. For each question, there are five possible answers, in this scale 5 is the best condition, and 1 the worst condition, except in questions 3,4 and 26 with reverse score ${ }^{(16)}$.

The Oral Health Impact Profile - 14 (OHIP-14) was also applied, in a short version of OHIP-49, which was validated in Brazil(14) and selected for being a specific instrument to individually assess certain aspects of QoL changed due to oral health condition in the perception of people $e^{(15)}$. This instrument consists of 14 questions divided into seven domains: Functional Limitation, Physical Pain, Psychological Discomfort, Physical Disability, Psychological Disability, Social Disability and Handicap. Each question has five possible answers, with score of 1 to 5 , where 1 is best condition and 5 the worst condition ${ }^{(17)}$.

The questionnaires were applied in two stages: approximately 3 days prior to the surgical correction of dentofacial deformity (pre-surgical), and from 3 to 12 months after surgery (post-surgery).

For the analysis of the WHOQOL-Bref, we performed the transformation of the scale values from 4 to 20 points proportionally to values from 0 to 100 in each domain, and 
general quality of life questions, the higher the score, the better the QoL ${ }^{(16)}$. For the analysis OHIP-14 different weights were assigned for each question ${ }^{(17)}$ and, considering that the instrument has seven domains, by adding the final score, this may vary between 0 and 28 points, thus, close to zero scores are related to lower impact of oral health on $\mathrm{QoL}^{(14-15,17)}$. Data were stored in Microsoft Excel version 2007 spreadsheet and comparisons between the two investigated periods were performed by the " $\mathrm{t}$ " test for paired samples in the analysis of the WHOQOL-Bref, and the Wilcoxon test in the analysis of OHIP-14. The significance level of 5\% was considered.

The study started after approval by the Research Ethics Committee of the institution (Letter No. 93/2013-SVAPEPECEP), and it was conducted in accordance with the ethical standards required. Individuals who met the inclusion criteria were invited to participate, with appropriate explanations about the research, and those who agreed, formalized their participation by signing the Consent Form, being assured of their confidentiality.

\section{RESULTS}

A total of 50 individuals were included. Of these, 29 were men $(58 \%)$ and 21 women $(42 \%)$, with a mean age of 24 years; $66 \%$ had complete/incomplete high school, $32 \%$ complete/incomplete college education and $2 \%$ complete primary education; $92 \%$ were single and $8 \%$ married; $46 \%$ lived in Sao Paulo and 54\% in other states. The participants responded to the WHOQOL-Bref and OHIP-14 questionnaire, approximately 3 days before and 3 to 12 months after surgery. The period between surgery and the interview was from 3 to 11 months, with mean of 6 months.

The results of WHOQOL-Bref and OHIP-14 are shown in Tables 1 and 2, respectively. From the four areas analyzed by the WHOQOL-Bref, except for the domain Social Relationship, after surgery, the scores were higher, as well as to the General Questions, indicating improvement in QoL; and the seven domains analyzed by OHIP-14, four domains changed after surgery, with lower scores (Psychological Discomfort, Psychological Disability, Social Disability and Handicap), as well as the Overall Score, showing that there was a positive impact of oral health condition in QoL, after correction of dentofacial deformity.

Table 1 - Mean scores of domains and overall quality of life WHOQOL-Bref before and after surgical correction of dentofacial deformity - Bauru, SP, Brazil, 2014.

\begin{tabular}{|c|c|c|c|c|c|c|}
\hline Domains & & Mean & Standard deviation & Minimum & Maximum & $P$ value \\
\hline Physical & $\begin{array}{l}\text { Pre } \\
\text { Post }\end{array}$ & $\begin{array}{l}79.64 \\
82.50\end{array}$ & $\begin{array}{l}8.96 \\
7.47\end{array}$ & $\begin{array}{l}53.57 \\
64.29\end{array}$ & $\begin{array}{c}100.00 \\
96.43\end{array}$ & $\mathrm{p}=0.034^{*}$ \\
\hline Psycological & $\begin{array}{l}\text { Pre } \\
\text { Post }\end{array}$ & $\begin{array}{l}74.58 \\
80.92\end{array}$ & $\begin{array}{c}11.43 \\
9.42\end{array}$ & $\begin{array}{l}50.00 \\
58.33\end{array}$ & $\begin{array}{c}95.83 \\
100.00\end{array}$ & $\mathrm{p}<0.001^{*}$ \\
\hline Social Relationship & $\begin{array}{l}\text { Pre } \\
\text { Post }\end{array}$ & $\begin{array}{l}81.00 \\
83.50\end{array}$ & $\begin{array}{l}16.67 \\
15.01\end{array}$ & $\begin{array}{l}33.33 \\
33.33\end{array}$ & $\begin{array}{l}100.00 \\
100.00\end{array}$ & $p=0.164$ \\
\hline Environment & $\begin{array}{l}\text { Pre } \\
\text { Post }\end{array}$ & $\begin{array}{l}72.69 \\
75.50\end{array}$ & $\begin{array}{l}10.49 \\
11.56\end{array}$ & $\begin{array}{c}50.00 \\
50.00\end{array}$ & $\begin{array}{l}93.75 \\
96.88\end{array}$ & $\mathrm{p}=0.034^{*}$ \\
\hline General Questions & $\begin{array}{l}\text { Pre } \\
\text { Post }\end{array}$ & $\begin{array}{l}82.75 \\
87.75\end{array}$ & $\begin{array}{l}12.34 \\
10.86\end{array}$ & $\begin{array}{l}62.50 \\
62.50\end{array}$ & $\begin{array}{l}100.00 \\
100.00\end{array}$ & $\mathrm{p}=0.014^{*}$ \\
\hline
\end{tabular}

*Higher score after surgery.

Table 2 - Mean scores of domains and the overall score of the OHIP-14 before and after surgical correction of dentofacial deformity - Bauru, SP, Brazil, 2014.

\begin{tabular}{|c|c|c|c|c|c|c|}
\hline Domains & & Mean & Standard deviation & Minimum & Maximum & $P$ value \\
\hline Functional Limitation & $\begin{array}{l}\text { Pre } \\
\text { Post }\end{array}$ & $\begin{array}{l}0.88 \\
0.75\end{array}$ & $\begin{array}{l}0.69 \\
0.74\end{array}$ & $\begin{array}{l}0.00 \\
0.00\end{array}$ & $\begin{array}{l}2.53 \\
2.04\end{array}$ & $\mathrm{p}=0.359$ \\
\hline Physical Pain & $\begin{array}{l}\text { Pre } \\
\text { Post }\end{array}$ & $\begin{array}{l}0.42 \\
0.33\end{array}$ & $\begin{array}{l}0.83 \\
0.55\end{array}$ & $\begin{array}{l}0.00 \\
0.00\end{array}$ & $\begin{array}{l}4.00 \\
1.98\end{array}$ & $p=0.633$ \\
\hline Psychological Disconfort & $\begin{array}{l}\text { Pre } \\
\text { Post }\end{array}$ & $\begin{array}{l}1.16 \\
0.45\end{array}$ & $\begin{array}{l}1.19 \\
0.87\end{array}$ & $\begin{array}{l}0.00 \\
0.00\end{array}$ & $\begin{array}{l}4.00 \\
4.00\end{array}$ & $\mathrm{p}<0.001^{*}$ \\
\hline Physical Disability & $\begin{array}{l}\text { Pre } \\
\text { Post }\end{array}$ & $\begin{array}{l}0.28 \\
0.16\end{array}$ & $\begin{array}{l}0.57 \\
0.46\end{array}$ & $\begin{array}{l}0.00 \\
0.00\end{array}$ & $\begin{array}{l}2.08 \\
2.52\end{array}$ & $\mathrm{p}=0.241$ \\
\hline Psychological Disability & $\begin{array}{l}\text { Pre } \\
\text { Post }\end{array}$ & $\begin{array}{l}0.96 \\
0.29\end{array}$ & $\begin{array}{l}0.77 \\
0.48\end{array}$ & $\begin{array}{l}0.00 \\
0.00\end{array}$ & $\begin{array}{l}2.80 \\
2.40\end{array}$ & $\mathrm{p}<0.001^{*}$ \\
\hline Social Disability & $\begin{array}{l}\text { Pre } \\
\text { Post }\end{array}$ & $\begin{array}{l}0.70 \\
0.40\end{array}$ & $\begin{array}{l}0.83 \\
0.66\end{array}$ & $\begin{array}{l}0.00 \\
0.00\end{array}$ & $\begin{array}{l}3.62 \\
2.00\end{array}$ & $\mathrm{p}=0.027^{*}$ \\
\hline Handicap & $\begin{array}{l}\text { Pre } \\
\text { Post }\end{array}$ & $\begin{array}{l}0.39 \\
0.09\end{array}$ & $\begin{array}{l}0.75 \\
0.30\end{array}$ & $\begin{array}{l}0.00 \\
0.00\end{array}$ & $\begin{array}{l}4.00 \\
1.18\end{array}$ & $\mathrm{p}=0.001^{*}$ \\
\hline Overall Score & $\begin{array}{l}\text { Pre } \\
\text { Post }\end{array}$ & $\begin{array}{l}4.79 \\
2.48\end{array}$ & $\begin{array}{l}3.79 \\
2.66\end{array}$ & $\begin{array}{l}0.00 \\
0.00\end{array}$ & $\begin{array}{l}13.7 \\
9.99\end{array}$ & $\mathrm{p}<0.001^{*}$ \\
\hline
\end{tabular}

*Lower score after surgery. 


\section{DISCUSSION}

The objective of the study was to assess the pre- and post-surgical correction QoL of people with dentofacial deformity, through the WHOQOL-Bref and OHIP-14 instruments in individuals with cleft lip and palate, aged over 18 years old. This surgery for dentofacial deformity correction is performed after the conclusion of facial growth ${ }^{(18)}$, which justified the sample having mean age of 24 years.

Other studies have also investigated the QoL from the sixth month postoperatively ${ }^{(8,19)}$, and for some authors, the deterioration of QoL caused by the pain and the functional limitations is manifested mainly in the first six weeks after surgery, and may impact QoL negatively ${ }^{(9,19)}$. Immediately after surgery, a study showed transient impairment in QoL, justified by the authors by common surgical morbidities, such as pain, swelling, temporary limitation in mouth opening and reduced masticatory efficiency ${ }^{(6)}$. These events may justify the assessment of QoL in this study, as it was performed 3 days before and 3 to 12 months after surgery, with mean of six months; and the positive results that were found.

The WHOQOL-Bref results showed difference after dentofacial deformity correction surgery, with the highest scores for the domains: Physical, Psychological and Environment, as well as for General Questions. These results indicate that the perception of the individual had an improvement in $\mathrm{QoL}$ in these aspects, which can be attributed to physical changes with the change in facial appearance caused by surgery ${ }^{(8)}$. For General Questions, positive perception of the individual in relation to QoL and general health is probably associated with improvement in the Physical, Psychological and Environment domains, which influenced the QoL of the individual in a positive way. These results corroborate studies which analyzed subjects without cleft lip and palate, which, despite using other instruments, found improvement in $\mathrm{QoL}^{(8-9)}$, as well as studies using, among others, the OHIP-14 ${ }^{(6,19-20)}$. Thus, the positive changes observed in these domains and in the General Questions of WHOQOL-Bref can be related to the period of data collection after surgery, a mean of six months, considering the adaptation to the new facial appearance and return to social and professional activities, it would justify the improvement of QoL.

The Physical domain is also related to satisfaction with the performance of activities of daily life and the ability to work. Also, the Psychological domain is related to the acceptance of physical appearance and self-satisfaction. While the Environment domain includes the sense of security in their daily life and leisure activity opportunities.

However, the Social Relationship domain showed no difference between pre and post-surgical periods, justified by high scores before surgery. Studies related to the rehabilitation of cleft lip and palate emphasized the importance of the work done by a multidisciplinary team with an interdisciplinary approach characterized by humanized care and comprehensive treatment ${ }^{(1,21-22)}$, structure present in the institution where the study was conducted ${ }^{(1,2,4)}$.

Positive changes in $\mathrm{QoL}$ after dentofacial deformity surgery evidenced by the WHOQOL-Bref, reflects the work of multi and interdisciplinary teams in the institution $^{(1)}$. It can also be associated to the fact that changes are perceived by individuals when cleft lip and palate and dentofacial deformities were repaired, leading to positive impact on $\mathrm{QoL}^{(18)}$. In some studies, using the WHOQOL, it was found that, in general, individuals with cleft lip and palate show good QoL. In adults with cleft lip and palate surgically repaired, the WHOQOL-Bref showed adequate QoL domains for Physical, Social Relationship and the Environment ${ }^{(23)}$. In a study of adolescents and adults, there was little difference in relation to psychological adjustment between individuals with and without cleft lip and palate ${ }^{(24)}$.

The OHIP-14 is an instrument that specifically investigates questions related to the oral cavity and allows indication of the QoL dimensions compromised by oral condition $^{(15)}$. In individuals without cleft lip and palate, a study showed that QoL is affected by dentofacial deformity ${ }^{(25)}$. In adults with severe bad occlusion, it was found that the domains Physical Pain, Psychological Disability and Handicap were the most negatively affected before surgery $^{(26)}$. The OHIP-14 results obtained in this study showed lower scores for the domains: Psychological Discomfort, Psychological Disability, Social Disability and Handicap, as well as the overall score after surgery, which indicates positive impact of oral health on QoL in these areas after correction of dentofacial deformity.

Positive changes of the OHIP-14 domains in this study may be related to the fact that the surgery provided improved emotional states related to body image, increased self-esteem, self-confidence, among others ${ }^{(9)}$. Thus, the results of this study can be justified by the fact that surgical correction benefits dental occlusion, facial aesthetics and $\mathrm{QoL}^{(21)}$.

Using the OHIP-14, the results showed impairment of QoL due to dentofacial deformity, with a positive impact of oral health on QoL after correction of this deformity, which demonstrates aesthetic, functional and psychosocial benefits after orthodontic-surgical treatment. Personal presentation is part of the process of social integration ${ }^{(9)}$, the positive changes in self-esteem, self-confidence and the strengthening of affective and family ties ${ }^{(27)}$. With the modification of facial appearance, it was expected that the investigated aspects presented positive changes. Considering two important aspects of the concept of quality of life: subjectivity and multidimensionality, which involves the individual's perception of the success of treatment in the dimensions related to quality of life ${ }^{(11)}$.

Thus, the lack of guidance on surgery may cause impairment to the patient and increase suffering, which shows the importance of health professionals in providing information and confidence with regard to the performance of successful treatment ${ }^{(9)}$. The promotion of care, educational guidance and family integration for the continuity of care at home after hospital discharge is clearly necessary ${ }^{(3,5)}$; and the importance of treatment strategies directed at individuals with cleft lip and palate to meet expectations and satisfaction with the results ${ }^{(28)}$.

Assessing QoL enables the multidisciplinary team, working in the rehabilitation of individuals with cleft lip and palate, a reflection of the success of the treatment 
applied to the correction of dentofacial deformity, as identifying areas with greater disability allows them to review offered proposals for intervention, in order to contribute to the improvement of service quality and consequently the promotion of health. Thus, the hypothesis was confirmed, allowing to state that orthognathic surgery improves the aspects of QoL, with a positive impact of oral health.

\section{CONCLUSION}

The results showed positive changes in QoL and the impact of oral health conditions after surgical correction of dentofacial deformity of individuals with cleft lip and palate, even with the decrease of cases after surgery in the initial proposal, which is a limitation of the study.

In the assessment of QoL after surgery, WHOQOLBref showed improvement in the domains Physical, Psychological, Environmental and General Questions, which did not occur for the domain Social Relationship, which had high score even before the surgery; OHIP-14 showed improvement in the domains Psychological Discomfort, Psychological Disability, Social Disability and Handicap, as well as the Overall Score after surgery, indicating the positive impact of oral health on QoL in these domains after surgical correction of dentofacial deformity.

\section{RESUMO}

Objetivo: Avaliar a qualidade de vida e o impacto das condições de saúde oral nos períodos pré e pós-correção cirúrgica da deformidade dentofacial de indivíduos com fissura labiopalatina operada. Método: Estudo quantitativo e prospectivo, realizado em um hospital de referência, no período de junho de 2011 a maio de 2013. Participaram 50 indivíduos que responderam aos questionários World Health Organization Quality of Life - Bref (WHOQOL-Bref) e Oral Health Impact Profile - 14 (OHIP-14), aproximadamente 3 dias antes e entre 3 e 12 meses após a cirurgia. Os testes " $t$ " para amostras pareadas e de Wilcoxon foram usados para análise estatística, com nível de significância de 5\%. Resultados: Após a cirurgia, foram encontradas diferenças nos domínios: Físico, Psicológico, Meio Ambiente e nas Questões Gerais do WHOQOL-Bref e nos domínios: Desconforto Psicológico, Limitação Psicológica, Limitação Social, Incapacidade e no Escore Geral do OHIP-14. Conclusão: A correção cirúrgica da deformidade dentofacial propiciou melhora da qualidade de vida e impacto positivo da condição da saúde oral.

\section{DESCRITORES}

Qualidade de Vida; Cirurgia Ortognática; Fenda Labial; Fissura Palatina; Anormalidades Maxilofaciais; Enfermagem.

\section{RESUMEN}

Objetivo: Evaluar la calidad de vida y el impacto de las condiciones de salud oral en los períodos pre y post corrección quirúrgica de deformidad dentofacial de individuos con fisura labiopalatina operada. Método: Estudio cuantitativo y prospectivo, llevado a cabo en un hospital de referencia, en el período de junio de 2011 a mayo de 2013. Participaron 50 individuos que respondieron a los cuestionarios World Health Organization Quality of Life - Bref(WHOQOL-Bref) y Oral Health Impact Profile - 14 (OHIP-14), aproximadamente tres días antes y entre tres y 12 meses después de la cirugía. Las pruebas " $t$ " para muestras pareadas y de Wilcoxon fueron utilizadas para el análisis estadístico, con nivel de significación del 5\%. Resultados: Luego de la cirugía, fueron encontradas diferencias en los dominios: Físico, Psicológico, Medio Ambiente y en las Cuestiones Generales del WHOQOL-Bref y en los dominios: Incomodidad Psicológica, Limitación Psicológica, Limitación Social, Incapacidad y en el Puntaje General del OHIP-14. Conclusión: La corrección quirúrgica de la deformidad dentofacial proporcionó mejora de la calidad de vida e impacto positivo de la condición de salud oral.

\section{DESCRIPTORES}

Calidad de Vida; Cirugía Ortognática; Labio Leporino; Fisura del Paladar; Anomalías Maxilofaciales; Enfermería.

\section{REFERENCES}

1. Freitas JAS, Neves LT, Almeida ALPF, Garib DG, Trindade-Suedam IK, Yaedú RYF, et al. Rehabilitative treatment of cleft lip and palate: experience of the Hospital for Rehabilitation of Craniofacial Anomalies/USP (HRAC/USP) - Part 1: overall aspects. J Appl Oral Sci. 2012;20(1):9-15.

2. Freitas JAS, Almeida ALPF, Soares S, Neves LT, Garib DG, Trindade-Suedam IK, et al. Rehabilitative treatment of cleft lip and palate: experience of the Hospital for Rehabilitation of Craniofacial Anomalies/USP (HRAC/USP) - Part 4: oral rehabilitation. J Appl Oral Sci. 2013;21(3):284-92.

3. Trettene AS, Mondini CCDS, Marques IL. Feeding children in the immediate perioperative period after palatoplasty: a comparison between techniques using a cup and a spoon. Rev Esc Enferm USP. 2013;47(6):1298-304.

4. Freitas JAS, Garib DG, Trindade-Suedam IK, Carvalho RM, Oliveira TM, Lauris RCMC, et al. Rehabilitative treatment of cleft lip and palate: experience of Hospital for Rehabilitation of Craniofacial Anomalies-USP (HRAC-USP) - Part 3: oral and maxillofacial surgery. J Appl Oral Sci. 2012;20(6):673-9.

5. Trettene AS, Razera APR, Maximiano TO, Luiz AG, Dalben GS, Gomide MR. Doubts of caregivers of children with cleft lip and palate on postoperative care after cheiloplasty and palatoplasty. Rev Esc Enferm USP. 2014;48(6):993-8.

6. Choi WS, Lee S, McGrath C, Samman N. Change in quality of life after combined orthodontic-surgical treatment of dentofacial deformities. Oral Surg Oral Med Oral Pathol Oral Radiol Endod. 2010;109(1):46-51.

7. Peres KG, Cascaes AM, Leão ATT, Côrtes MIS, Vettore MV. Sociodemographic and clinical aspects of quality of life related to oral health in adolescents. Rev Saúde Pública. 2013;47 Suppl 3:19-28. 
8. Murphy C, Kearns G, Sleeman D, Cronin M, Allen PF. The clinical relevance of orthognathic surgery on quality of life. Int J Oral Maxillofac Surg. 2011;40(9):926-30.

9. Carvalho SC, Martins EJ, Barbosa MR. Variáveis psicossociais associadas à cirurgia ortognática: uma revisão sistemática da literatura. Psicol Reflex Crit. 2012;25(3):477-90.

10. Soh CL, Narayanan V. Quality of life assessment in patients with dentofacial deformity undergoing orthognathic surgery: a systematic review. Int J Oral Maxillofac Surg. 2013; 42(8):974-80.

11. Seidl EMF, Zannon CMLC. Qualidade de vida e saúde: aspectos conceituais e metodológicos. Cad Saúde Pública. 2004;20(2):580-8.

12. Herkrath APCQ, Herkrath FJ, Rebelo MAB, Vettore MV. Measurement of health-related and oral health-related quality of life among individuals with nonsyndromic orofacial clefts: a systematic review and meta-analysis. Cleft Palate Craniofac J. 2015;52(2)157-72.

13. Fleck MPA, Louzada S, Xavier M, Chachamovich E, Vieira G, Santos L, et al. Aplicação da versão em português do instrumento abreviado de avaliação da qualidade de vida "WHOQOL-bref". Rev Saúde Pública. 2000;34(2):178-83.

14. Oliveira BH, Nadanovsky P. Psychometric properties of the brazilian version of the oral health impact profile-short form. Community Dent Oral Epidemiol. 2005;33(4):307-14.

15. Slade GD, Spencer AJ. Development and evaluation of the oral health impact profile. Community Dent Health. 1994;11(1):3-11.

16. World Health Organization. WHOQOL-BREF: introduction, administration, scoring and generic version of the assessment. Field trial version. Geneva: WHO; 1996.

17. Slade GD. Derivation and validation of a short-form oral health impact profile. Community Dent Oral Epidemiol. 1997;25(4):284-90.

18. Lopes JFS, Pinto JHN, Lopes MMW, Mazottini R, Soares S. Interrelationship between implant and orthognathic surgery for the rehabilitation of edentulous cleft palate patients: a case report. J Appl Oral Sci. 2015;23(2):224-9.

19. Lee S, McGrath C, Samman N. Impact of orthognathic surgery on quality of life. J Oral Maxillofac Surg. 2008;66(6):1194-9.

20. Rustemeyer J, Gregersen J. Quality of life in orthognathic surgery patients: post-surgical improvements in aesthetics and self-confidence. J Craniomaxillofac Surg. 2012;40(5):400-4.

21. Freitas JAS, Trindade-Suedam IK, Garib DG, Neves LT, Almeida ALPF, Yaedú RYF, et al. Rehabilitative treatment of cleft lip and palate: experience of the Hospital for Rehabilitation of Craniofacial Anomalies/USP (HRAC/USP) - Part 5: institutional outcomes assessment and the role of the Laboratory of Physiology. J Appl Oral Sci. 2013;21(4):383-90.

22. Gil-da-Silva-Lopes VL, Monlleó IL. Risk factors and the prevention of oral clefts. Braz Oral Res. 2014;28(spe):1-5.

23. Pinto RR, Oliveira FP, Trindade Junior AS. Qualidade de vida em adultos com fissura labiopalatina. Bol Acad Paulista de Psicologia. 2012;32(82):75-87.

24. Pisula E, Lukowska E, Fudalej PS. Self-esteem, coping styles, and quality of life in polish adolescents and young adults with unilateral cleft lip and palate. Cleft Palate Craniofac J. 2014;51(3):290-9.

25. Frejman MW, Vargas IA, Rösing CK, Closs LQ. Dentofacial deformities are associated with lower degrees of self-esteem and higher impact on oral health-related quality of life: results from an observational study involving adults. J Oral Maxillofac Surg. 2013;71(4):763-7.

26. Rusanen J, Lahti S, Tolvanen M, Pirttiniemi P. Quality of life in patients with severe malocclusion before treatment. Eur J Orthod. 2010;32(1):43-8

27. Silva CM, Locks A, Carcereri DL, Silva DGV. School in health promotion for children with cleft lips and palates. Texto Contexto Enferm. 2013;22(4):1041-8.

28. Gkantidis N, Papamanou DA, Karamolegkou M, Dorotheou D. Esthetic, functional, and everyday life assessment of individuals with cleft lip and/or palate. BioMed Res Int. 2015;510395:1-8.

Financial support: Coordenação de Aperfeiçoamento de Pessoal de Nível Superior (CAPES). 